\title{
Effect of intravenous administration of glucagon- like peptide 1 on growth hormone secretion in sheep
}

\author{
Y. Kurose ${ }^{1}$, A. Kuwahara, Y. Oshiba, H. Takahashi, Y. Watanabe \\ and Y. Terashima
}

Faculty of Animal Science, Kitasato University

Towada-shi, Aomori 034-8628 Japan

\begin{abstract}
We examined effects of intravenous administration of glucagon-like peptide 1 (GLP-1) on growth hormone $(\mathrm{GH})$ secretion in ruminants. Four Suffolk rams, aged 2 years, were fed at $16.00 \mathrm{~h}$. They were bled every $5 \mathrm{~min}$ from 12.00 until $17.00 \mathrm{~h}$. GLP-1(7-36)amide was intravenously infused at a rate of $1.2 \mathrm{pmol} / \mathrm{kg} / \mathrm{min}$ from 12.00 to $17.00 \mathrm{~h}$. GH peak frequency was significantly $(\mathrm{P}<0.05)$ increased. GLP-1 did not affect GH peak amplitude. Plasma insulin levels transiently increased just after the start of GLP-1 infusion. Plasma glucose levels did not change. GLP-1 may be a physiological regulator of spontaneous pulsatile GH secretion in ruminants.
\end{abstract}

KEY WORDS: glucagon-like peptide 1, GH, insulin, glucose, sheep

\section{INTRODUCTION}

Glucagon-like peptide 1 (GLP-1) is a peptide, which is secreted from the intestine into the circulation and enhances both insulin release (Schmidt et al., 1985) and synthesis (Drucker et al., 1987). GLP-1 receptors have been found in the anterior pituitary (Alvarez et al., 1996), whereas the role of GLP-1 on the secretion of anterior pituitary hormones has been scarcely examined. It has been reported that GLP-1 reduces GH responses during hypoglycaemia in humans (Nauck et al., 2002). We examined effects of continuous administration of GLP-1 on plasma $\mathrm{GH}$, insulin, and glucose levels in sheep.

\section{MATERIAL AND METHODS}

Four Suffolk rams, aged 2 years, were kept in metabolism crates in a controlled environmental room at $24^{\circ} \mathrm{C}$ under a 12-h light-dark cycle $(07.30-19.30 \mathrm{~h}$, light;

\footnotetext{
${ }^{1}$ Corresponding author: e-mail: kurose@vmas.kitasato-u.ac.jp
} 
19.30-07.30 h, dark). The rams were fed a sufficient quantity of lucerne hay cubes to meet $120 \%$ of their daily metabolizable energy requirements at $16.00 \mathrm{~h}$, and allowed free access to water throughout the experiment. The animals received right and left jugular catheters. At first, the animals were subjected to saline infusion, and three days later, the same animals were subjected to GLP-1 infusion. Blood samples were collected from the right jugular venous at 5 min intervals from 12.00 until 17.00 h. Control animals were subjected to a continuous administration of $0.9 \%$ saline containing $0.1 \%$ ovine albumin at a rate of $1 \mathrm{ml} / \mathrm{min}$. GLP-1(7-36)amide, dissolved in the saline, was infused into the left jugular venous at a rate of $1.2 \mathrm{pmol} / \mathrm{kg} / \mathrm{min}$ over $5 \mathrm{~h}$ (from 12.00 to $17.00 \mathrm{~h}$ ). Blood samples were immediately placed into heparinized tubes with aprotinin $(5000 \mathrm{KIU} / \mathrm{ml}$ of blood) and centrifuged for $10 \mathrm{~min}$ at $4^{\circ} \mathrm{C}$. Harvested plasma was stored at $-80^{\circ} \mathrm{C}$ until assay. Plasma $\mathrm{GH}$ and insulin concentrations were measured by time-resolved fluoro-immunoassay (TR-FIA). The blood glucose levels were determined by an automated glucose analyser on the basis of glucose oxidase reaction. The pulsatile patterns of GH secretions were analysed in individual animals using the PULSAR program.

\section{RESULTS}

GLP-1 produces modest increases in mean concentration and peak frequency of circulating GH (Figure 1). There was a marginally insignificant effect of GLP-1 treatment on mean $\mathrm{GH}(\mathrm{P}=0.054)$, but a significant effect on peak frequency
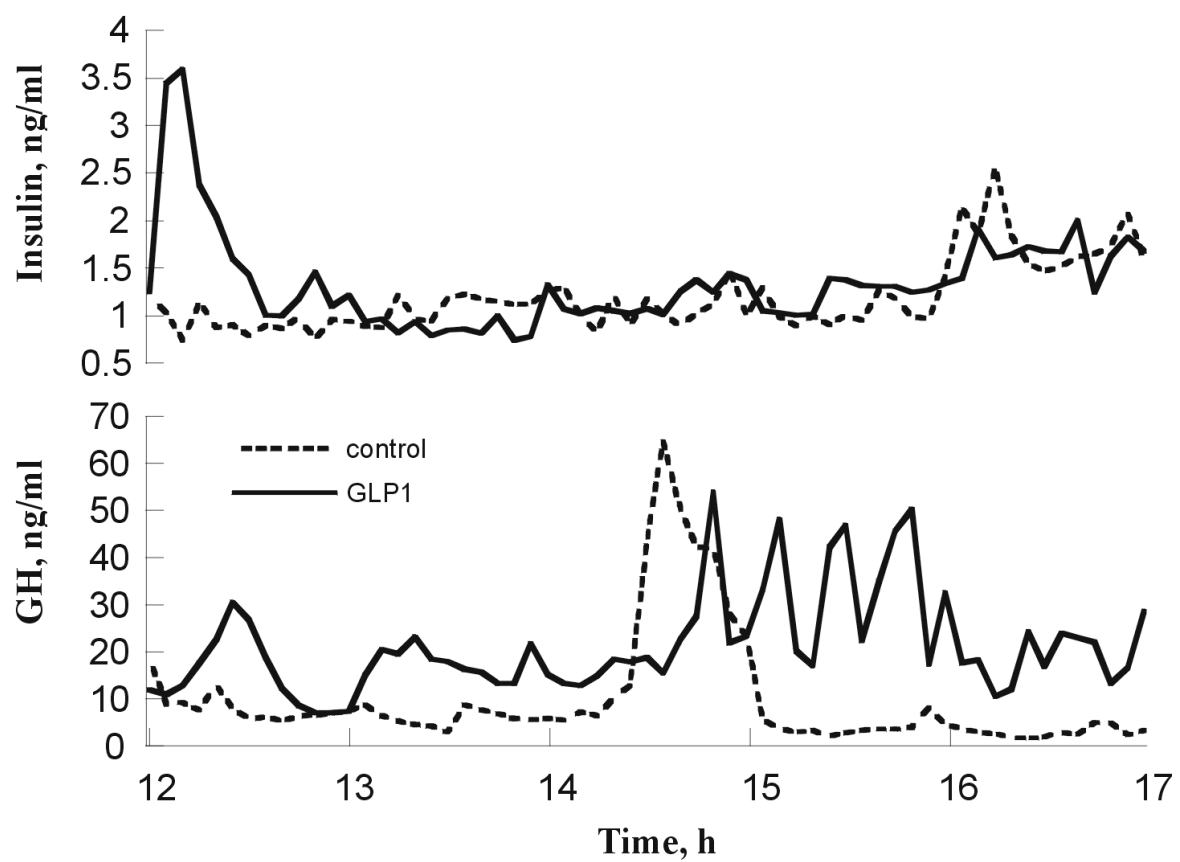

Figure 1. Representative profile of plasma GH and insulin levels in sheep treated with GLP-1 
$(\mathrm{P}<0.05)$. GLP-1 did not affect GH peak amplitude. Plasma insulin concentrations were transiently increased just after the start of GLP-1 infusion (Figure 1). There was no treatment effect in plasma glucose levels.

\section{DISCUSSION}

The profiles of GH secretion were variable according to individuals. However the results of pulse analysis suggested that GLP-1 might influence pulsatile GH secretion. The stimulatory effect of GLP-1 on insulin secretion was temporal, suggesting that GLP-1 stimulates insulin release but does not enhance its synthesis in sheep. Accordingly, the stimulatory effects of GLP-1 on pulsatile GH secretion might not be due to the changes in circulating insulin levels. These results indicate that GLP-1 is a physiological regulator of spontaneous pulsatile GH secretion in ruminants.

\section{REFERENCES}

Alvarez E., Roncero I., Chowen J.A., Thorens B., Blazquez E., 1996. Expression of the glucagonlike peptide-1 receptor gene in rat brain. J. Neurochem. 66, 920-927

Drucker D.J., Philippe J., Mojsov S., Chick W.L., Habener J.F., 1987. Glucagon-like peptide 1 stimulates insulin gene expression and increases cyclic AMP levels in a rat islet cell line. Proc. Nat. Acad. Sci. USA 84, 3434-3438

Nauck M.A., Heimesaat M.M., Behle K., Holst J.J., Nauck M.S., Ritzel R., Hufner M., Schmiegel W.H., 2002. Effects of glucagon-like peptide 1 on counterregulatory hormone responses, cognitive functions, and insulin secretion during hyperinsulinemic, stepped hypoglycemic clamp experiments in healthy volunteers. J. Clin. Endocrinol. Metab. 87, 1239-1246

Schmidt W.E., Siegel E.G., Creutzfeldt W., 1985. Glucagon-like peptide-1 but not glucagon-like peptide-2 stimulates insulin release from isolated rat pancreatic islets. Diabetologia 28, 704707 